$$
D O E / E A--1107-P t .1
$$

\title{
Cultural Resource Survey Report For Conștruction of Office Building, Driveway, and Parking Lot at the Stanford Linear Accelerator Center
}

\author{
January 1995 \\ Submitted To: \\ United States Department of Energy \\ Oakland, California \\ On Behalf of: \\ Stanford Linear Accelerator Center \\ Stanford, California \\ Prepared By: \\ Michael E. Perry \\ Uribe and Associates \\ 2930 Lakeshore Avenue, Suite 200 \\ Oakland, California \\ With Contributions By: \\ Laura Jones, Ph.d \\ Campus Archeologist \\ Planning Office, Stanford University \\ Stanford, California
}




\section{TABLE OF CONTENTS}

EXECUTIVE SUMMARY .1

1 INTRODUCTION 2

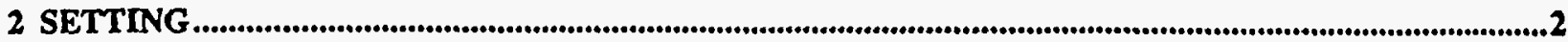

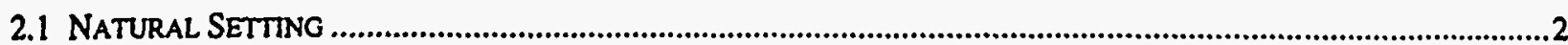

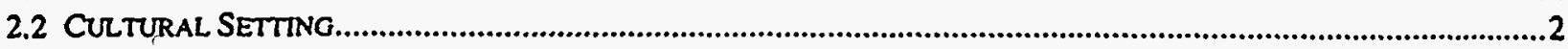

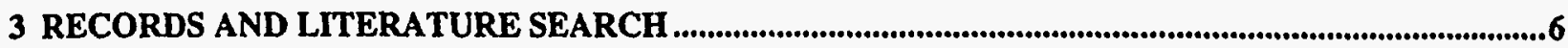

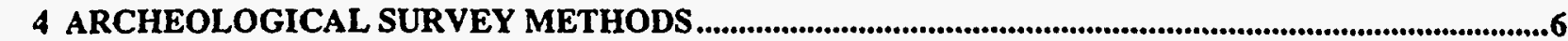

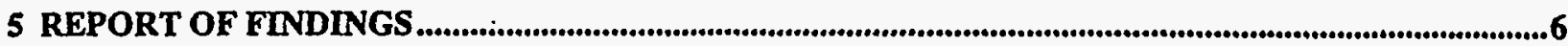

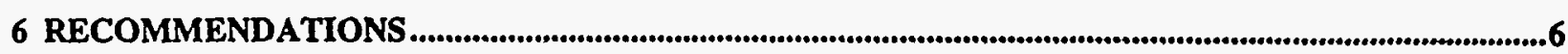

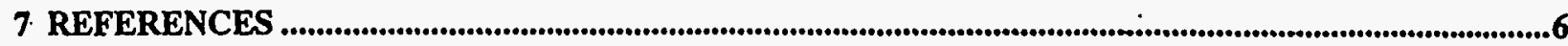

\section{List of Figures}

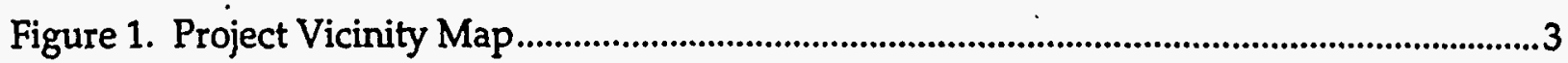

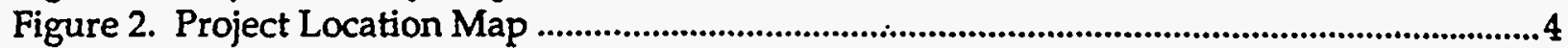

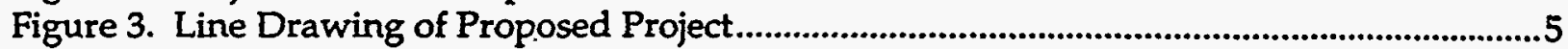

\section{DISCLAIMER}

This report was prepared as an account of work sponsored by an agency of the United States Government. Neither the United States Government nor any agency thereof, nor any of their employees, makes any warranty, express or implied, or assumes any legal liability or responsibility for the accuracy, completeness, or usefulness of any information, apparatus, product, or process disclosed, or represents that its use would not infringe privately owned rights. Reference herein to any specific commercial product, process, or service by trade name, trademark, manufacturer, or otherwise does not necessarily constitute or imply its endorsement, recommendation, or favoring by the United States Government or any agency thereof. The views and opinions of authors expressed herein do not necessarily state or reflect those of the United States Government or any agency thereof. 


\section{DISCLAIMER}

\section{Portions of this document may be illegible}

in electronic image products. Images are produced from the best available original document. 


\section{Cultural Resource Survey Report \\ For Construction of Office Building, Driveway, and Parking Lot at the Stanford Linear Accelerator Center}

\section{Executive Summary}

On 30 November 1994, a records and literature search and cultural resource survey were accomplished for a proposed undertaking at the Stanford Linear Accelerator Center in Stanford, California. The proposed project involves the placement of a new building, driveway, and parking lot at the Stanford Linear Accelerator Center. The records search and cultural resource survey did not locate historic resources that are listed or eligible for listing within the National Register of Historic Places within the area of potential effect. Therefore, the Department of Energy requests that the California Office of Historic Preservation concur in a "no effect" determination for the proposed undertaking.

Qualifications: Mr. Michael E. Perry has over 14 years of archeological survey and report preparation on a wide variety of projects on federal, state, and private properties throughout California and Nevada. Doctor Jones has provided archeological surveys and documentation for the SLAC for several years. She is the Stanford University campus archeologist. 


\section{Introduction}

Uribe and Associates has been subcontracted by the United States Department of Energy (DOE) to prepare an Environmental Assessment and associated documentation for the construction of an office building and parking lot in support of environmental management personnel activities. As part of the documentation process, the DOE determined that the proposed project constituted an undertaking as defined in Section 106 of the National Historic Preservation Act. In accordance with the regulations (36 CFR 800) implementing Section 106 of the National Historic Preservation Act, a records and literature search and historic resource identification effort were carried out on behalf of the Stanford Linear Accelerator Center (SLAC). This report summarizes cultural resource literature and record searches and a historic resource identification effort conducted by Doctor Jones of Stanford University.

The SLAC has been in continuous use for over 25 years in the study of elementary particle physics and for the development of new techniques in high energy acceleration and elementary particle detection. The proposed buildings will provide additional office space for hazardous waste management personnel. The map included as Figure 1 depicts the project location within the state of California. The map included as.Figure 2 depicts the area of potential effect (APE) for the proposed undertaking. The drawing included as Figure 3 depicts the conceptual plans for the proposed construction.

\section{Setting}

\subsection{Natural Setting}

The proposed project occurs in an undeveloped area in proximity to buildings, landscaped areas, and parking lots. Tall grasses predominate throughout the project area. Unobstructed view of the ground surface is possible in most areas of the project; however, tall grasses do obscure about 20 percent of the ground surface. The project area is generally flat with little or no noticeable topography or elevation. Plant overstory is rare within the project area; however, isolated oak trees do occur relatively close to the project area. Decomposing cherts are present throughout the project area. Soils at the project site include decomposing plant and lithic materials in primarily alluvial deposition.

\subsection{Cultural Setting}

The region was home to hunter-gatherer groups who congregated primarily by the San Francisquito stream margins but small family groups may have seasonally transhumed through the project area to exploit both static and mobile resources. Large prehistoric village sites have been recorded along stream margins and on hillsides. These sites often included massive concentrations of flaked-stone lithic debitage and tools, house rings, food production areas, and associated midden deposits. Smaller sites in the area include lithic concentrations, resource procurement sites and campsites, and flaked or ground stone isolated materials. Historic use of the area may have included mining, ranching, and some historic settlement. 


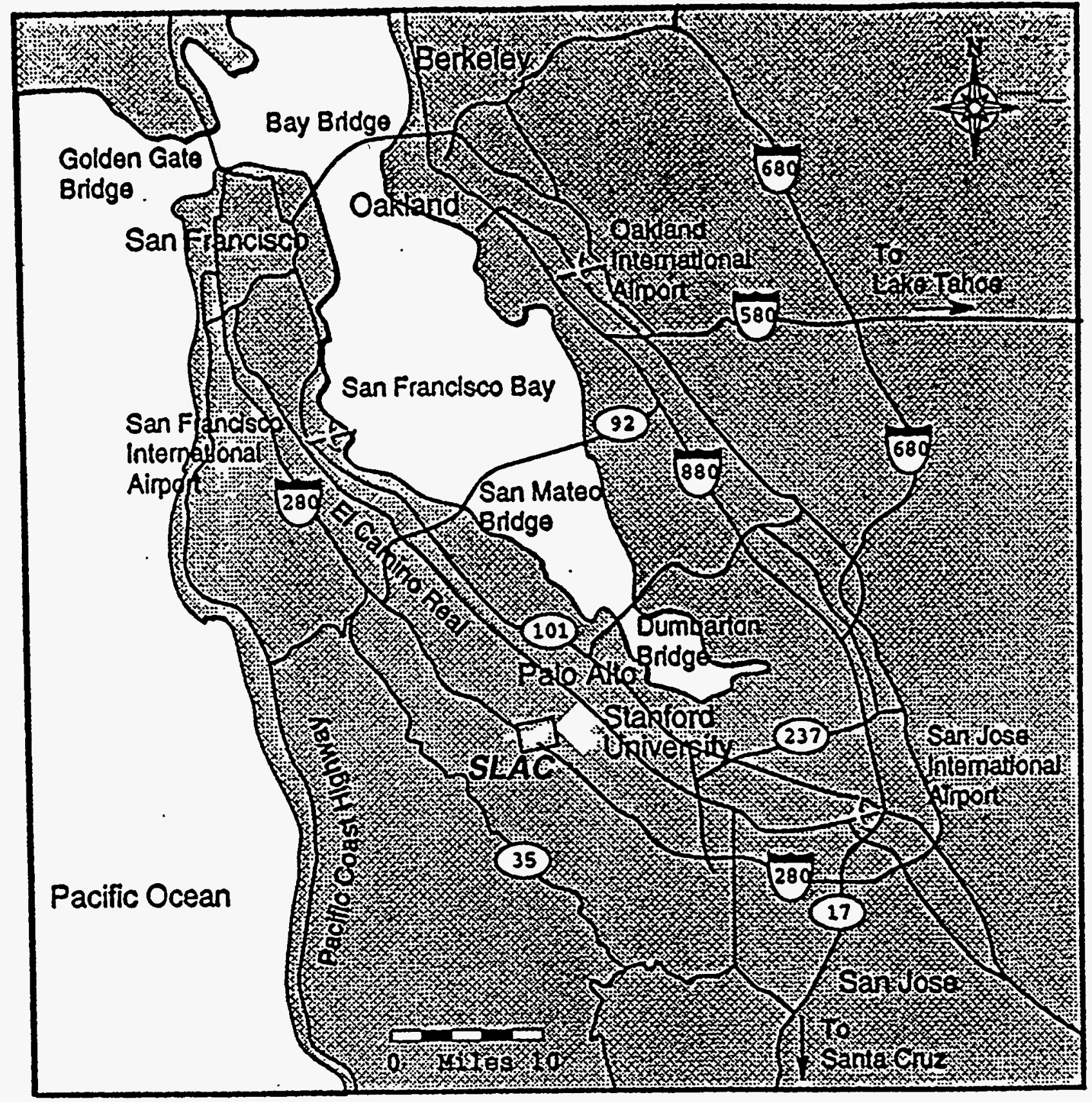

Figure 1. Project Location Map for Construction of Office Building, Driveway, and Parking Lot at SLAC 


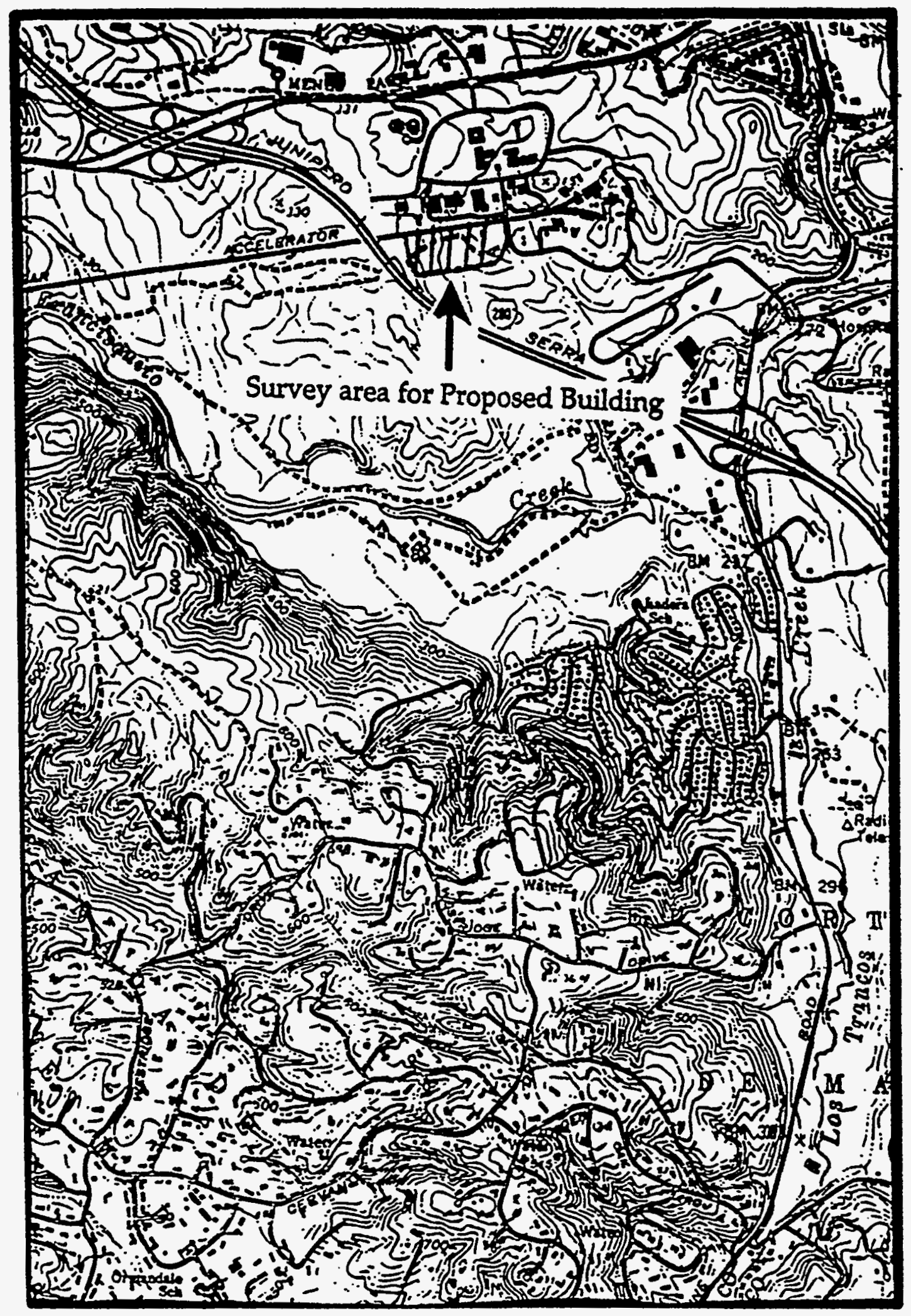

Figure 2. Area of Potential Effect for Propọsed Undertaking. Portion of Palo Alto 7.5 Quadrangle. 


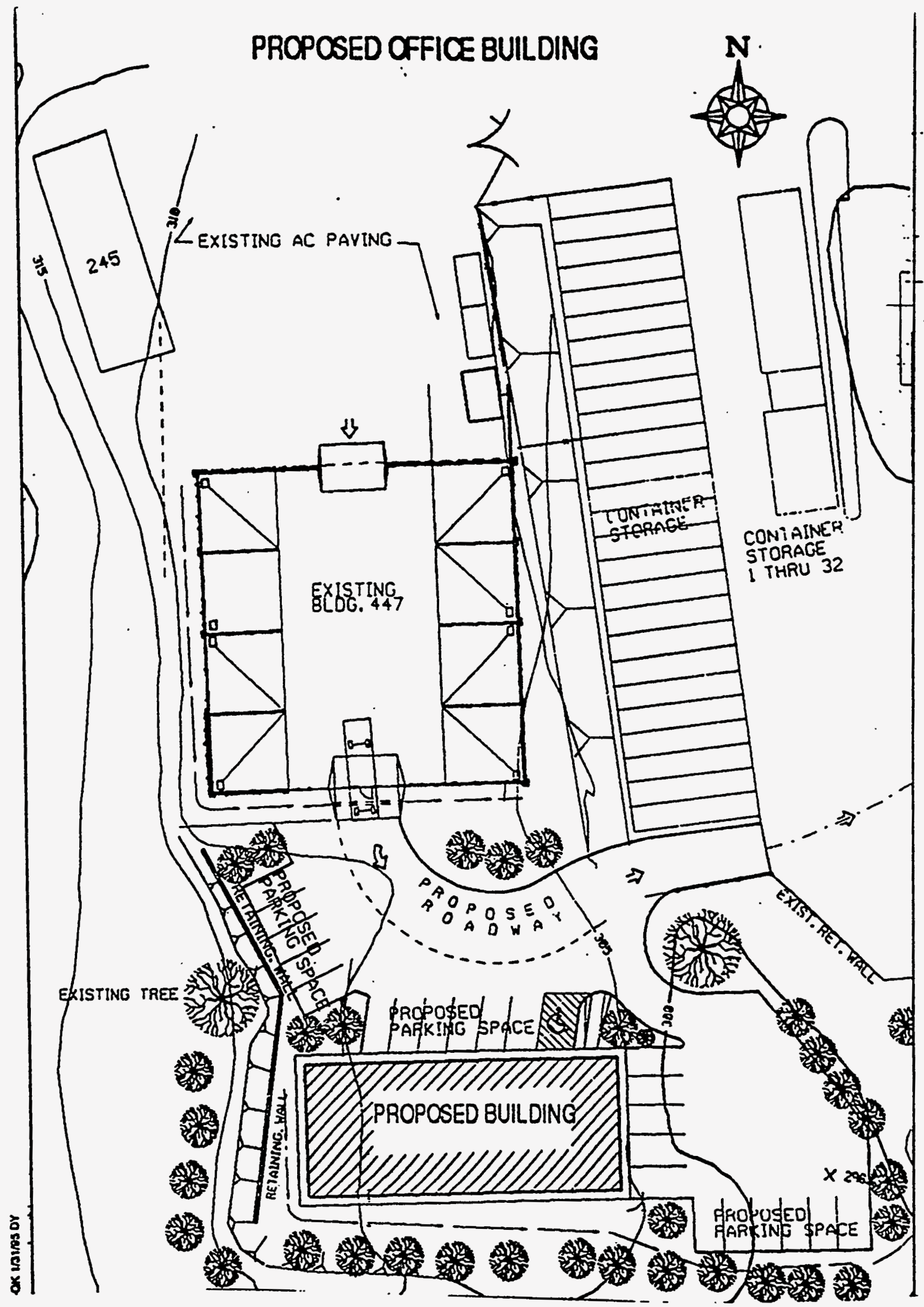

Figure 3. Line Drawing for Proposed Building, Driveway, and Parking Lot within Stanford Linear Accelerator Center 


\section{Records and Literature Search}

A records and literature search was conducted at Stanford University for the project area and a one mile vicinity by Doctor Laura Jones, Campus Archeologist, Stanford University on 30 November 1994 (Jones, 1994a). The records available at the university mirror the archived records at the Information Center at Sonoma State University. Additionally, Doctor Jones consulted the National Register of Historic Places. Both searches revealed that previously recorded cultural resources that are eligible or listed within the National Register of Historic Places are not located within the area of potential effect or a one mile vicinity of the project area.

\section{Archeological Survey Methods}

Doctor Jones conducted parallel transect reconnaissance of the entire area. Survey methods met or exceeded U.S. Department of Interior guidelines and included pedestrian transects of less than 25 meters in a south to north orientation across the project area (Jones, 1994b). The project area is less than 15 acres in size. Additionally, she carefully inspected areas without ground cover to ensure that flaked-stone lithic debitage or associated cultural materials were not present. These ground inspections employed an enhanced survey methodology which included 5 meter parallel transects across areas with exposed soils (Jones, 1994b).

\section{Report of Findings}

Cultural materials were not found as a result of this historic resource identification effort.

\section{Recommendations}

Since cultural resources that are eligible or listed within the National Register of Historic Places were not found during the records search or historic resource identification effort, the DOE recommends that the California Office of Historic Preservation concur in a "no effect" determination for the proposed project. Based on the absence of historic resources within the area of potential effect and low sensitivity of the project area for prehistoric and historic cultural resources, the DOE has determined that additional protective measures such as monitoring or oversight activities during construction are not required.

\section{References}

Jones, Laura

1994a Personal Communications Regarding Records and Literature Searching for the location of a proposed building and parking lot at SLAC. November, 1994.

1994b Report on a Reconnaissance Survey at the Stanford Linear Accelerator Center, Proposed Environmental Safety and Health Office Buildings. On file at Uribe and Associates, Oakland, CA. 


\section{OFFICE OF HISTORIC PRESERVATION}

\section{DEPARTMENT OF PARKS AND RECREATION}

P.O. BOX 942800

SACAAMENTO 91296-0001

(016) 6536624

FAX: (916) 653-2024

(916) 653-6624

FAX (916) 653-9824

Anthony J. Adduci

DEO/OAK NEPA Compliance Officer

Department of Energy

oakland Operations office

1301 Clay street

OAKLAND CA 94612-5208

Re: Construction of an office Building at the Stanford Iinear Accelerator Center, Palo Alto, Santa Clara County.

Dear Mr. Adduci:

Thank you for submitting to our office your July 3, 1995 letter and Environmental Assessment (EA) regarding the proposed construction of an office building at the stanford Linear Accelerator Center (SLAC), Palo Alto, Santa clara County. The proposed office building is expected to assist waste management (WM) operations at SLAC in becoming more efficient and effective. The building would located on an undeveloped, grassy area of approximately one acre, 50 feet south of the existing centralized Hazardous Waste Management facility, Building 447.

You are seeking our comments on your determination of the effects of the proposed project on historic resources in accordance with Section 106 of the National Historic Preservation Act (NHPA). Our review of the submitted documentation leads us to concur with your determination that the proposed project, as described, will not involve historic resources. Accordingly, your agency's responsibilities under 36 CFR 800 , regulations implementing section 106 of the NHPA, have been fulfilled. However, there may be additional section 106 responsibilities under certain circumstances set forth in 36 CFR 800 .

Thank you again for seeking our comments on your project. If you have any questions, please contact staff historian clarence Caesar at (916) 653-8902.

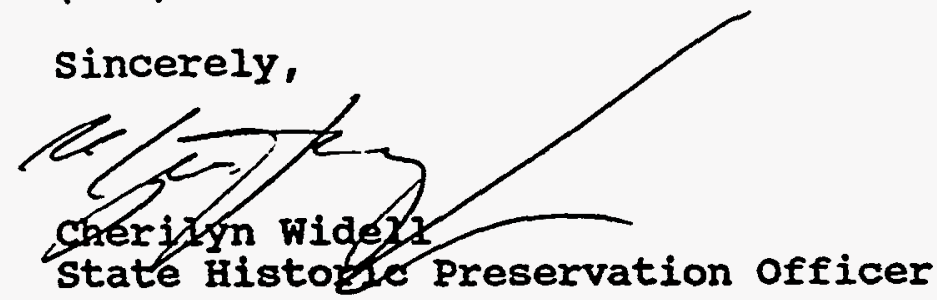




\section{Department of Energy \\ Oakland Operations Office \\ 1301 Clay Street \\ - Oakland, California 94612.5208 \\ SEP 2019995}

Mr. Ruben Niño

Director of Engineering Services

City of Menlo Park

701 Laurel Street

Menlo Park, CA 94025

Subject: Final Environmental Assessment for the Construction and Operation of an Office Building at the Stanford Linear Accelerator Center.

Dear Mr. Niño:

The Environmental Assessment. (EA) for the Construction and Operation of an Office Building at the Stanford Linear Accelerator Center (SLAC) has been finalized and approved. Comments received from your office were forwarded to SLAC and the applicable ones were incorporated in the Final EA. A Finding of No Significant Impact (FONSI) along with the Final EA were signed on September 8, 1995. A copy of the FONSI is enclosed. The EA is available upon request.

Should you have any questions, please call me at (510) 637-1522.

Sincerely,

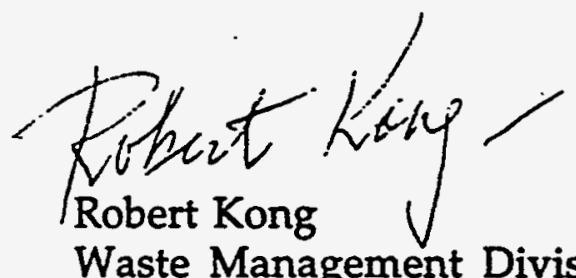

Waste Management Division

Enclosure

ce:

A. Adduci, NCO 


\section{Department of Energy \\ Oakland Operations Office \\ 1301 Clay Street \\ Oakland, California 94612-5208 \\ SEP 201995}

Mr. Terry Burns

Planning Administrator

San Mateo County Planning Department

590 Hamilton Street

Redwood City, CA 94063

Subject: Final Environmental Assessment for the Construction and Operation of an Office Building at the Stanford Linear Accelerator Center.

Reference: Letter from R. Kong to T. Burns dated July 7, 1995, "Distribution of Draft Environmental Assessment for the Construction and Operation of an Office Building at the Stanford Linear Accelerator Center"

Dear Mr. Burns:

The Environmental Assessment (EA) for the Construction and Operation of an Office Building at the Stanford Linear Accelerator Center has been finalized and approved. A Finding of No Significant Impact (FONSI) along with the Final EA were signed on September 8, 1995. A copy of the FONSI is enclosed. The EA is available upon request.

Should you have any questions, please call me at (510) 637-1522.

Sincerely,

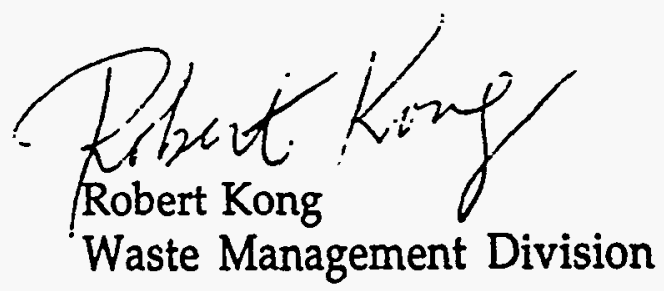

Enclosure

ce. A. Adduci, NCO 


\section{Department of Energy \\ Oakland Operations OHice \\ 1301 Clay Street}

Oakland, California 94612-5208

September 12, 1995

Ms Terry Rivasplata

State Clearing House

Office of Planning and Research

1400 Tenth Street, Rm. 121

Sacramento, CA 95814

Dear Ms Rivasplata:

The Environmental Assessment (EA) for the Construction and Operation of an Office Building at the Stanford Linear Accelerator Center in Menlo Park, Califormia has been finalized and approved. A Finding Of No Significant Impact (FONSI) along with the EA were signed on September 8, 1995. Both documents, the EA and the FONSI, are available for review upon request.

If you have any questions or need any further information please contact me or Jacqueline White at 510-637-1807 or 510-637-1972 respectively. We may also be reached at the address shown on the letter.
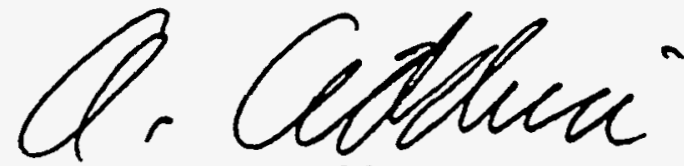

Anthony J. Adduci

DOE/OAK NEPA Compliance Officer 


\section{Department of Energy \\ Oakland Operations Office \\ 1301 Clay Street \\ Oakland, California 94612-5208}

September 12, 1995

Rosemary Cambra

Ohlone Families Consulting Services

1845 The Alameda

San Jose, CA 95126

Dear President Cambra:

The Environmental Assessment (EA) for the Construction and Operation of an Office Building at the Stanford Linear Accelerator Center in Menlo Park, California has been finalized and approved. A Finding Of No Significant Impact (FONSI) along with the EA were signed on September 8, 1995. Both documents, the EA and the FONSI, are available for review upon request.

If you have any questions or need any further information please contact me or Jacqueline White at 510-637-1807 or 510-637-1972 respectively. We may also be reached at the address shown on the letter.
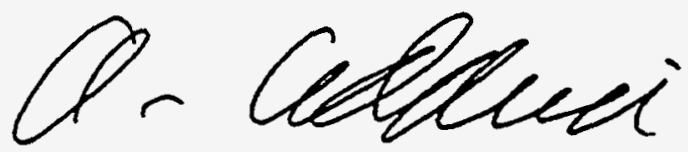

Anthony J. Adduci DOE/OAK NEPA Compliance Officer 


\section{Department of Energy}

Oakland Operations Office

1301 Clay Street

Oakland. California 94612-5208

$$
7 / 7 / 95
$$

Mr. Terry Burns

Planning Administrator

San Mateo County Planning Department

590 Hamilton Street

Redwood City, CA 94063

Subject: Distribution of Draft Environmental Assessment for the Construction and Operation of an Office Building at the Stanford Linear Accelerator Center.

Dear Mr. Burns:

We have prepared the enclosed Draft Environmental Assessment (EA) for a proposed office building at the Stanford Linear Accelerator Center at 2575 Sand Hill Road in Menlo Park, California. The center is dedicated to research in elementary particle physics and in those fields that make use of its synchrotron facilities. Please feel free to distribute this EA to others that may have comments.

Please send written comments to:

\section{Robert Kong \\ U.S. Department of Energy \\ Waste Management Division \\ 1301 Clay Street, Rm. 700N \\ Oakland, CA 94612}

before August 11, 1995.

Should you have any questions, please call me at (510) 637-1522.

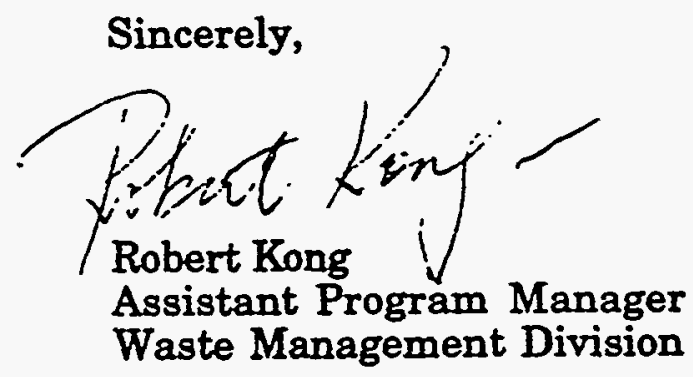

Enclosure 


\section{Department of Energy}

Oakland Operations OHtice

1301 Clay Street

Oakland. California 94612.5208

$$
7 / 7 / 95
$$

Ms. Karen Fedrickson

Library Director

Menlo Park Library

800 Alma Street

Menlo Park, CA 94025

Subject: Distribution of Draft Environmental Assessment for the Construction and Operation of an Office Building at the Stanford Linear Accelerator Center.

Dear Ms Fedrickson:

We have prepared the enclosed Draft Environmental Assessment (EA) for a proposed office building at the Stanford Linear Accelerator Center at 2575 Sand Hill Road in Menlo Park, California. The center is dedicated to research in elementary particle physics and in those fields that make use of its synchrotron facilities. You have been listed as a repository for this EA in a newspaper advertisement. The EA may be copied without restriction.

Written comments should be sent to:

$$
\begin{aligned}
& \text { Robert Kong } \\
& \text { U.S. Department of Energy } \\
& \text { Waste Management Division } \\
& \text { 1301 Clay Street, Rm. 700N } \\
& \text { Oakland, CA } 94612
\end{aligned}
$$

before August 11, 1995.

You may discard the Draft EA after that date. Should you have any questions, please call me at (510) 637-1522.

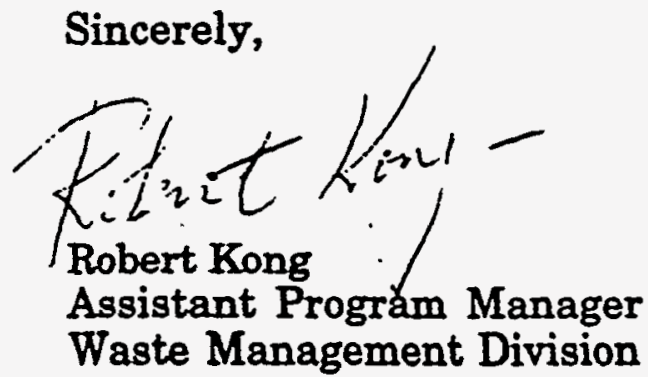

Enclosure 


\section{The Resources Agency}

Pete Wilson

Governor

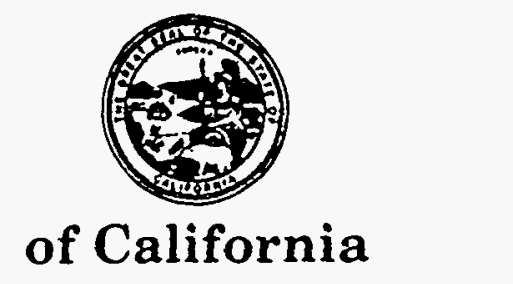

Douglas P. Wheeler Secretary

California Consenation Corps - Department of Busting s llatemass - Department of Consernation

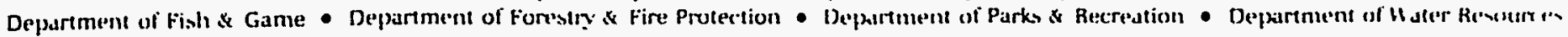

August 3, 1995

U. S. Department of Energy

ATTN : Anthony Adduci

1301 Clay Street

Oakland, California 94612

- Dear Mr. Adduci:

The State has reviewed the Environmental Assessment, for the Construction and Operation of an Office Building at the stanford Linear Accelerator Center, San Mateo County, submitted through the Office of Planning and Research.

We coordinated review of this document with the California Highway Patrol; the Public Utilities, and State Lands Commissions; the Air Resources, California Integrated Waste Management, and San Francisco Bay Regional water Quality Control Boards; and the Departments of Fish and Game, and Transportation.

None of the above-listed reviewers has provided a comment regarding this document. Consequently, the state will have no comments or recommendations to offer. project.

Thank you for providing an opportunity to review this

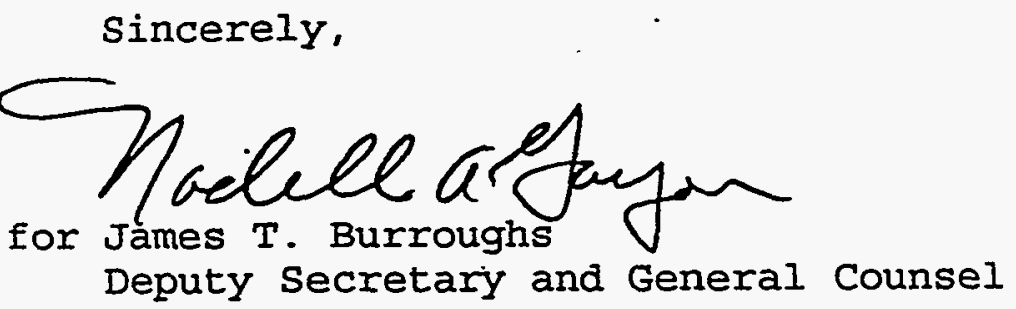

CC: Office of Planning and Research

1400 Tenth Street

Sacramento, CA 95814

( $\mathrm{SCH}$ 95074021)

The Resources Building Sacramento, CA 95814 (916) 653-5656 FAX (916) 653-8102

Callfornia Coastal Commission - California Tahoe Conservancy - Colorado River Board of California

Energy Resources, Conservation \& Development Commission - San Francisco Bay Conservation \& Development Commission State Coastal Conservancy • State Lands Commission • State Reclamation Board 


\section{Department of Energy \\ Oakland Operations Office \\ 1301 Clay Street \\ Oakland, California 94612-5208 \\ JUL 031995}

Ms. Terry Rivasplata

State Clearing House

Office of Planning and Research

1400 - 10th Street, Room 121

Sacramento, California 95814

Dear Ms. Rivasplata:

Enclosed are ten copies of the Environmental Assessment (EA) for the proposed construction of an office building at Stanford Linear Accelerator Center in Palo Alto, California, for your review and comment. A state distribution form is included with the Environmental Assessment.

This letter is to request review of the subject document by all of the cognizant California State agencies and that any and all comments be sent to this office by August 3,1995. If there is no response by the above date, it is assumed that you have no comments.

If there are any concerns or if further information is required, please phone me at (510) 637-1807 or write to me at the above address.

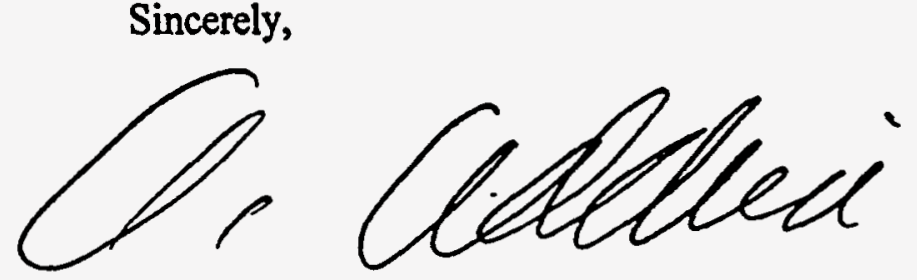

Anthony J. Adduci

DOE/OAK NEPA Compliance Officer

Enclosures 
- - - - - - - - - - - - - -

Document Typo

\begin{tabular}{|c|c|c|c|c|c|c|}
\hline CEQA: & $\begin{array}{l}\text { DNOP } \\
\text { DEarty Cons } \\
\text { Nes Dec } \\
\text { Dist ERR }\end{array}$ & $\begin{array}{l}\text { Dupplemenusubequent } \\
\text { DER (Prior SCH No.) } \\
\text { DOChe }\end{array}$ & NEPA: & $\begin{array}{l}\text { QNor } \\
\text { Bes } \\
\text { Dorat ars } \\
\text { DFCNsi }\end{array}$ & Orer: & 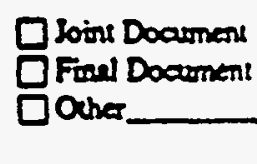 \\
\hline
\end{tabular}

\section{Loeal Aellon Typo} $-\infty$

DFCNSI

Toul Aare:

Werwery $-$
¿ General Pian Lipdue

Fenerd Plan Lipdare

Jenerd Pien Eiement

G Commurury Pian

\begin{tabular}{|c|c|}
\hline $\begin{array}{l}\square \text { Rezone } \\
D \text { Prezone } \\
\square \text { Use Permit } \\
\square \text { Lend Division (Subdivision. }\end{array}$ & $\begin{array}{l}\square \text { Annexusion } \\
\square \text { Redevelopment } \\
\square \text { Cossul Permit } \\
\square \text { Orem }\end{array}$ \\
\hline
\end{tabular}

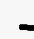

\section{Development Type}

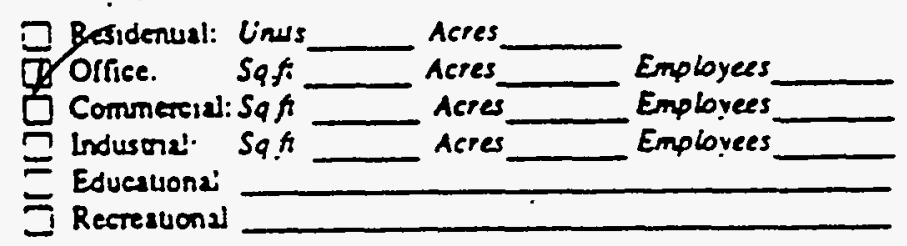

$\square$ Specific Plan
$\square$ Mester Plan
$\square$ Planned Unut Developmen
$\square$ Sice Plan

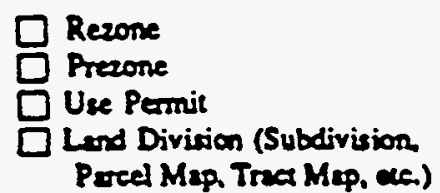

$\square$ Ansexution

Orher

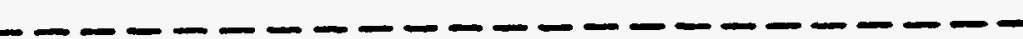




\section{Department of Energy \\ Oakland Operations Office \\ 1301 Clay Street}

Oakland, California 94612-5208

JUL 031995

State of California

Department of Parks and Recreation

Office of Historic Preservation

1416 - 9th Street

Sacramento, California 94296-0001

Attn: Clarence Caesar

Dear Mr. Caesar:

Enclosed is a copy of the Environmental Assessment for the proposed construction of an office building at Stanford Linear Accelerator Center in Palo Alto, California, for your review and comment. We ask that any and all comments be sent to this office by August 3,1995. If there is no response received by the above date, it is assumed that you have no comments.

If you have any questions or need any further information, please contact me at (510) 637-1807 or at the address on this letter.

Sincerely,
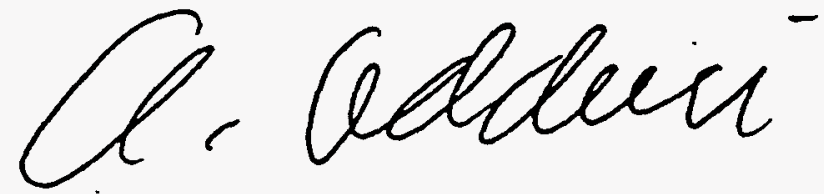

Anthony J. Adduci DOE/OAK NEPA Compliance Officer

Enclosure 


\section{Department of Energy}

Oakland Operations Office

1301 Clay Street

Oakland, California $94612-5208$

JUL 031995

Rosemary Cambra, President

Ohlone Families Consulting Services

1845 The Alameda

San Jose, California 95126

Dear President Cambra:

Enclosed is a copy of the Environmental Assessment for the proposed construction of an office building at Stanford Linear Accelerator Center in Palo Alto, California, for your review and comment. We ask that any and all comments be sent to this office by August 3,1995. If no response has been received by the above date, it will be assumed that you have no comments.

Should you have any questions or require further information regarding this effort, please phone me at (510) 637-1807 or write to me at the above address.

Sincerely,
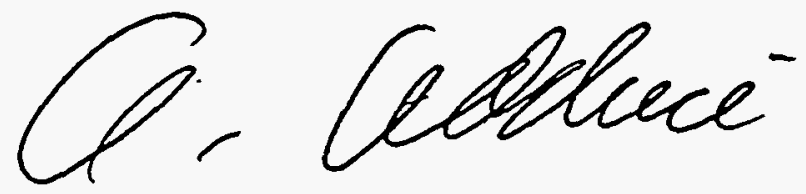

Anthony J. Adduci DOE/OAK NEPA Compliance Officer

Enclosure 